Journal of Environmental Science and Sustainable Development

$12-31-2019$

\title{
CHARACTERISTICS OF HABITAT, DISTRIBUTION, AND DIVERSITY OF ANOPHELES SPP IN KEMELAK BINDUNG LANGIT VILLAGE, OGAN KOMERING ULU REGENCY, SOUTH SUMATRA
}

\author{
Giri Maretasari \\ Biology Department, Mathematic and Natural Sciences Faculty Sriwijaya University \\ Yuanita Windusari \\ Biology Department, Mathematic and Natural Sciences Faculty Sriwijaya University, \\ ywindusari@yahoo.com \\ Syafrina Lamin \\ Biology Department, Mathematic and Natural Sciences Faculty Sriwijaya University \\ Laila Hanum \\ Biology Department, Mathematic and Natural Sciences Faculty Sriwijaya University
}

See next page for additional authors

Follow this and additional works at: https://scholarhub.ui.ac.id/jessd

Part of the Life Sciences Commons, Medicine and Health Sciences Commons, and the Social and Behavioral Sciences Commons

\section{Recommended Citation}

Maretasari, Giri; Windusari, Yuanita; Lamin, Syafrina; Hanum, Laila; and Septiawati, Dwi (2019).

CHARACTERISTICS OF HABITAT, DISTRIBUTION, AND DIVERSITY OF ANOPHELES SPP IN KEMELAK

BINDUNG LANGIT VILLAGE, OGAN KOMERING ULU REGENCY, SOUTH SUMATRA. Journal of

Environmental Science and Sustainable Development, 2(2), 165-175.

Available at: https://doi.org/10.7454/jessd.v2i2.1035

This Case-Based Article is brought to you for free and open access by the School of Environmental Science at UI Scholars Hub. It has been accepted for inclusion in Journal of Environmental Science and Sustainable Development by an authorized editor of UI Scholars Hub. 


\section{CHARACTERISTICS OF HABITAT, DISTRIBUTION, AND DIVERSITY OF}

ANOPHELES SPP IN KEMELAK BINDUNG LANGIT VILLAGE, OGAN KOMERING ULU REGENCY, SOUTH SUMATRA

\section{Authors}

Giri Maretasari, Yuanita Windusari, Syafrina Lamin, Laila Hanum, and Dwi Septiawati 


\title{
CHARACTERISTICS OF HABITAT, DISTRIBUTION, AND DIVERSITY OF ANOPHELES SPP IN KEMELAK BINDUNG LANGIT VILLAGE, OGAN KOMERING ULU REGENCY, SOUTH SUMATRA
}

\author{
Giri Maretasari, Yuanita Windusari*, Syafrina Lamin, Laila Hanum, Dwi Septiawati \\ Biology Department, Mathematic and Natural Sciences Faculty Sriwijaya University
}

*Corresponding author: e-mail: ywindusari@yahoo.com

(Received: 5 November 2019; Accepted: 12 December 2019; Published: 31 December 2019)

\begin{abstract}
Malaria is an infectious disease caused by Plasmodium and is transmitted through the bite of a female Anopheles vector. Ogan Komering Ulu (OKU) is a district in South Sumatra that is endemic to malaria. The study aims to determine habitat type, environmental factors that influence larvae development, and distribution of Anopheles larvae. The experiment was conducted from January to February 2019 in the Kelurahan Kemelak Bindung Langit, OKU. Species identification was carried out in the Entomology Laboratory, Baturaja Health Research and Development Center, OKU. Sampling locations were determined based on field observations, through simple purposive sampling. Identification of mosquito larvae which were maintained in the laboratory, showed that they originated from four Anopheles species namely An. vagus, An. barbirostris, An. kochi, and male Anopheles. The dominant habitat $(76,89 \%)$ was rice fields. The characteristics of larval breeding habitats included water $\mathrm{pH}$ of 5-6, water temperature of $28^{\circ} \mathrm{C}-32^{\circ} \mathrm{C}$, light intensity of $756-761 \mathrm{mmHg}$, visual clear water, muddy substrates, and habitat distance with houses of $10-60 \mathrm{~m}$. The Anopheles type diversity index ( $\left.\mathrm{H}^{\prime}\right)$ was low (0.04-0.36). The larval density was the highest in RT 1 and RT 2 (as many as 2.5 larvae/cauldrons), and the lowest in RW 3 locations (as many as 0.1 larvae/cauldron), which had the same habitat type, namely, rice fields. The highest dominance index $(\mathrm{C})$ was found in male Anopheles $(\mathrm{C}=1)$, and the lowest was detected in An. kochi $(\mathrm{C}=0.02)$ and An. barbirostris $(\mathrm{C}=0.01)$. The pattern of the spread of Anopheles based on the Morishita index was grouped (Id>1) and uniform (Id <1).
\end{abstract}

Keywords: Anopheles sp.; malaria; habitat characteristics; distribution; species diversity; morishita index

\section{Introduction}

Insects are fauna identified as $70 \%$ inhabiting the surface of the earth. Some groups of insects, such as mosquitoes, are dangerous to human health (Kardinan \& Dhalimi, 2010). Malaria is an infectious disease caused by parasites from the genus Plasmodium. These parasites live and multiply in human blood cells. Malaria is transmitted through the bite of a female Anopheles mosquito vector; and affects individuals of all ages, including infants, children, and pregnant women (Putra, 2011).

South Sumatra Province has 17 districts and cities, of which 8 are included in malaria endemic areas. Data show that 8 people per 1000 residents of South Sumatra are at risk of contracting malaria. In 2012, the values of the Annual Parasitic Incident (API) were 0.62 and 
0.44 per 1.000 indicents in South Sumatra and Ogan Komering Ulu (OKU) Regency, respectively. The Lengkiti Subdistrict is one of the sub-districts in OKU district and consists of 21 villages, where in a high number of positive malaria cases have been reported. The API value for Lengkiti Regency is 13.02 per 1,000 events (Mahdalena \& Tanwirotun, 2016).

The role of Anopheles as a malaria vector differs for each region, and is influenced by geographical and environmental conditions. Each region has different species, bioecology, habitat, distribution, and density. The existence and survival of Anopheles larvae are strongly influenced by the condition of the parent breeding site (Nurhayati, Hasanudin, \& Anwar, 2015).

Changes in the environment cause the individuals in it will adapt. Genetic characteristics are directly related to the presence of a population in the environment. These include, among others, the harmony of reproduction, distribution, adaptation and survival. Genetic factors in studying ecology have an important role because of genetic diversity will greatly determine the existence of a population in the environment. The age distribution in the population will greatly affect the natality and mortality which in turn affects the population density. In nature the environment is always limited (biotic and abiotic factors limit growth). The existence of limiting factors causes growth in nature to have certain patterns. Exponential growth in nature can occur for a while, then some biotic and abiotic factors such as food sources, partners, competition, climate and other factors limit it.

Malaria vectors can be grouped based on breeding location into three types, namely rice fields, hills or forests, and beaches or river flows. The behavior and breeding characteristics of malaria vectors are important to know and could be used as basis in determining interventions for vector control. Munif (2005) stated that environmental conditions affect the composition and type of Anopheles species in various types of habitats.

Kemelak OKU village has many paddy fields or swamps that are the source of life for the people. Puddles in rice fields or swamps with typical turbidity are habitats for Anopheles spp to lay eggs and incubate larvae (Permadi, Lasbudi, \& Yahya, 2018). Data from the Ministry of Health of the Republic of Indonesia (2017) shows that Kemelak Bindung Langit Village is one of malaria endemic areas in the medium category. Based on the statements stated above, this study was important conducted to investigate the habitat characteristics, distribution, and diversity of Anopheles spp. in the village of Kemelak Bindung Langit, OKU.

\section{Methods}

The study was conducted from January to February 2019, in the Kemelak Bindung Langit Village, OKU Regency, South Sumatra. The village has an area of 30-35 ha and consists of 426 family heads and 12 neighborhoods. Four sampling locations were determined based on observations through purposive sampling. Areas that are thought to be larval habitats include rice fields, tire treads of motor vehicles, rivers, fish ponds, old wells, duck ponds, waterways, and swamps.

Larvae were collected as follows (1) In habitats with a large amount of larvae were collected based on the WHO standards with a tool that is $300 \mathrm{ml}$ in size and $13 \mathrm{~cm}$ in diameter and equipped with a $1 \mathrm{~m}$ long stick, (2) In habitats with limited amount of water, larvae were collected using a pipette and put placed directly into a plaque bottle. Collection was repeated 10 times (Mandasari, 2012). The collected larvae of Anopheles spp were maintained in a sugar solution and fed in the form of beef liver pellets. The larvae were grown until the adult stage 
for identification. Maintenance and species identification were carried out at the Entomology Laboratory of the Baturaja Health Research and Development Center.

Identification of Anopheles type was conducted using the mosquito identification book by O'Connor \& Soepanto (1999). The physical parameters observed were water $\mathrm{pH}$, temperature, and turbidity, as well as light intensity, presence of aquatic plants and larvae predators, and distance of larval habitats with population settlement.

Data were analyzed to determine (1) the diversity index of Shannon Wiener species in accordance with the method of Magurran (1988), (2) index of species density in accordance with the Ministry of Health of the Republic of Indonesia (2003); (3) dominance index in accordance with the method of Odum (1993); and (4) distribution patterns based on the Morishita index in accordance with the method of Odum (1993).

\section{Results and Discussion}

\subsection{Morphology of Anopheles spp. Based on Habitat}

Based on observations in 19 sampling locations, only 10 were positive as habitat for Anopheles larvae. The 10 locations a rice fields, waterways, tire and the Anopheles spp present were An. vagus, An. barbirostris, An. kochi, and male Anopheles (Figure 1). The type of Anopheles was determined based on differences in morphology of the proboscis.

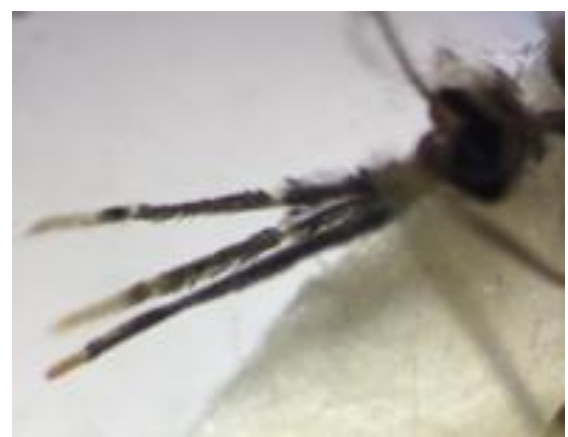

(a)

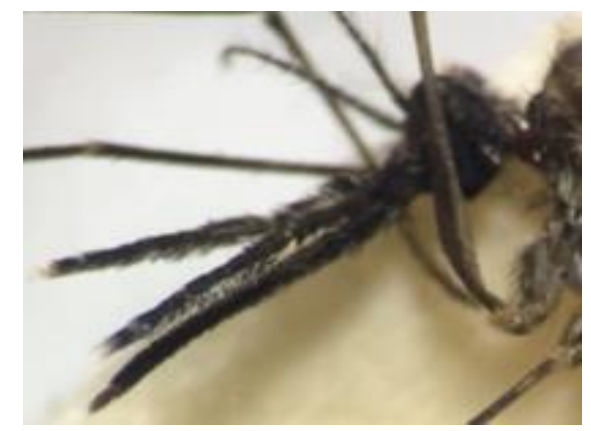

(c)

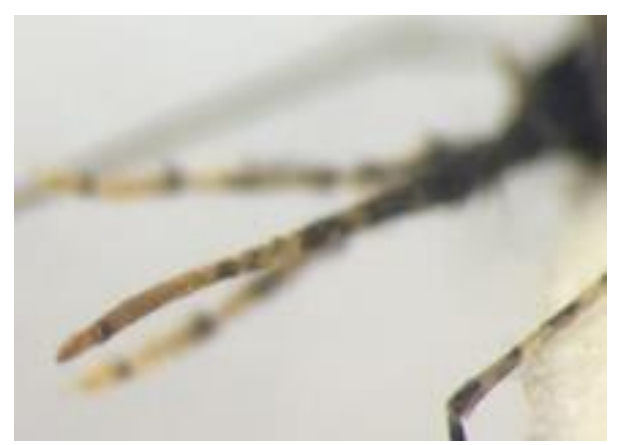

(b)

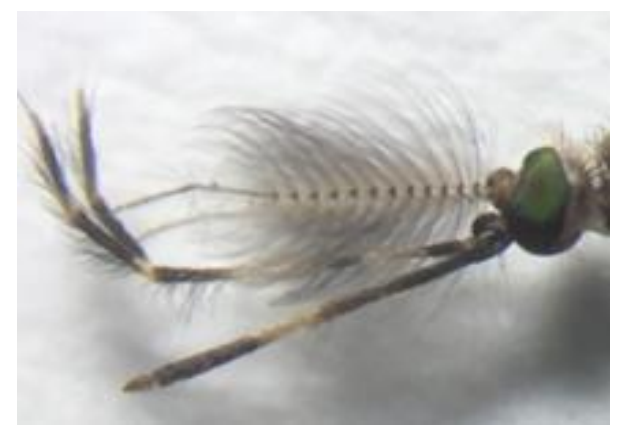

(d)

Figure 1. Morphology of Anopheles based on type of the proboscis: (a) An. vagus, (b) An. kochi, (c) An. barbirostris, and (d) male Anopheles 


\subsection{Types and Characteristics of Habitats}

Anopheles preferred laying larvae in rice fields, drains, and tire treads, and the characteristics of these habitats were determined based on physical and chemical factors observed. Among the total 228 observed populations, 183 were located in rice fields, 7 were located in water channels, and 38 were located in vehicle tire treads.

The types of Anopheles found in rice fields included An. vagus $q$ (44.81\%), An. barbirostris $q(0.55 \%)$, and Anopheles $\delta(54.64 \%)$. The species found in the vehicle tire included An. vagus $\supsetneq$ (52.63\%), An. kochi $\bigcirc$ (2.63\%), and Anopheles $\widehat{\gamma}$ (44.74\%). Although only 2 types of Anopheles, namely An. vagus $\$$ and Anopheles $\delta$ were found in water channels, their populations tended to be high $(42.86 \%$ and $57.14 \%$ respectively). Table 1 shows the results.

Table 1. Habitat, type, and percentage of Anopheles in each habitat

\begin{tabular}{|c|c|c|c|c|c|c|}
\hline \multirow[b]{2}{*}{ Species } & \multicolumn{6}{|c|}{ Type of habitat } \\
\hline & $\begin{array}{l}\text { Rice } \\
\text { fields }\end{array}$ & $\%$ & $\begin{array}{c}\text { Water } \\
\text { channel }\end{array}$ & $\%$ & $\begin{array}{c}\text { Vehicle tire } \\
\text { tread }\end{array}$ & $\%$ \\
\hline Anopheles vagus & 82 & 44.81 & 3 & 42.86 & 20 & 52.63 \\
\hline Anopheles barbirostris $q$ & 1 & 0.55 & - & - & - & \\
\hline Anopheles kochi + & - & - & - & - & 1 & 2.63 \\
\hline Anopheles ठิ & 100 & 54.64 & 4 & 57.14 & 17 & 44.74 \\
\hline Total & 183 & 100 & 7 & 100 & 38 & 100 \\
\hline
\end{tabular}

(Source: Maretasari, 2019)

Rice fields were the preferred habitat for Anopheles breeding, followed by stagnant water on the vehicle's tread, while waterways were the least preferred. This finding is presumably due to the availability of nutrients and the number of predators. The presence of water vegetation in rice fields has made them a comfortable place for teh growth and development of larvae. The physical and chemical characteristics of the habitats of Anopheles are shown in Table 2.

Mardiana, Shinta, Wigati, Enny, \& Sukijo (2002) stated that rice fields are a good breeding place for Anopheles larvae. In general, the types of Anopheles found in this habitat are An. vagus and An. barbirostris.

Table 2. Habitat characteristics based on physical and chemical factors

\begin{tabular}{|c|c|c|c|c|c|c|c|c|}
\hline $\begin{array}{c}\text { Type of } \\
\text { habitat }\end{array}$ & $\begin{array}{c}\text { Number } \\
\text { of habitat }\end{array}$ & $\begin{array}{c}\text { Distance } \\
(\mathbf{m})\end{array}$ & $\mathbf{p H}$ & $\begin{array}{c}\text { Temp } \\
\left({ }^{\circ} \mathbf{C}\right)\end{array}$ & $\begin{array}{c}\text { Light } \\
\text { intensity } \\
(\mathbf{m m H g})\end{array}$ & $\begin{array}{c}\text { Water } \\
\text { physics }\end{array}$ & Substrate & $\begin{array}{c}\text { Type of } \\
\text { Anopheles } \\
\text { spp. } .\end{array}$ \\
\hline Rice field & 7 & $15-60$ & $5-6$ & $29-31$ & $756-761$ & $\begin{array}{l}\text { Clear- } \\
\text { turbid }\end{array}$ & Mud & $\begin{array}{l}\text { An. vagus }+ \\
\text { An.barbirost } \\
\text { ris }+ \\
\text { Anopheles } \\
\hat{\sigma}\end{array}$ \\
\hline
\end{tabular}




\begin{tabular}{|c|c|c|l|c|c|c|c|c|}
\hline $\begin{array}{c}\text { Type of } \\
\text { habitat }\end{array}$ & $\begin{array}{c}\text { Number } \\
\text { of habitat }\end{array}$ & $\begin{array}{c}\text { Distance } \\
(\mathbf{m})\end{array}$ & $\mathbf{p H}$ & $\begin{array}{c}\text { Temp } \\
\left({ }^{\circ} \mathbf{C}\right)\end{array}$ & $\begin{array}{c}\text { Light } \\
\text { intensity } \\
(\mathbf{m m H g})\end{array}$ & $\begin{array}{c}\text { Water } \\
\text { physics }\end{array}$ & Substrate & $\begin{array}{c}\text { Type of } \\
\text { Anopheles } \\
\text { spp. }\end{array}$ \\
\hline $\begin{array}{c}\text { Water } \\
\text { channels }\end{array}$ & 1 & 10 & 6 & 31 & 760 & Turbid & Mud & $\begin{array}{l}\text { An. vagus } \text { }+ \\
\text { Anopheles } \\
\delta^{\lambda}\end{array}$ \\
\hline $\begin{array}{c}\text { Vehicle's } \\
\text { tread }\end{array}$ & 2 & 20 & 5 & $28-32$ & 759 & Turbid & Mud & $\begin{array}{l}\text { An. vagus } \text { }+ \\
\text { An. kochi } \text { }+ \\
\text { Anopheles } \\
\delta^{\lambda}\end{array}$ \\
\hline
\end{tabular}

(Source: Maretasari, 2019)

Table 2 shows that Anopheles larvae live in clear and muddy substrate water with $\mathrm{pH}$ of 56 , temperature of $28-32^{\circ} \mathrm{C}$, and light intensity of $756-761 \mathrm{mmHg}$. Mading \& Kazwaini (2014) explained that the general breeding habitats of Anopheles larvae are waters with direct sunlight exposure, which has an impact on increasing the water temperature. Sunlight and temperature affect the levels of dissolved oxygen in water and are important for the survival of larvae. The higher the temperature is, the lower the oxygen solubility is. At extreme temperatures Anopheles larvae cannot develop properly and can even cause death. The optimum average temperature for mosquito development is $25-27^{\circ} \mathrm{C}$ (Soekirno, Ariati, \& Mardiana, 2002; Susanto, 2013) and growth will stop if the temperature is less than $10^{\circ} \mathrm{C}$ or more than $40^{\circ} \mathrm{C}$. Mosquito metabolism is influenced by environmental temperature. Mosquitoes cannot regulate their body temperature and adjust to changes outside their body (Santoso, 2012).

Imron \& Munif (2010) reported on paddy planted rice fields discovered 33 mosquito species, which consist of 10 Anopheles spp., 5 malaria vectors, 13 Culex spp., 4 Aedes spp., and 1 kind of Mansonia and Ficalbia. An. aconitus, An. indefinites, and An. Anullaris will certainly be found in rice paddies and irrigation.

The presence of vegetation on the water surface plays a role in protecting larvae from predators and maintaining extreme temperatures. Susanna (2010) reported that the presence of aquatic plants is very important for mosquito larvae. The presence of vegetation in breeding places acts as a shelter, foraging, and shelter from the sun which can cause an increase in water temperature (Mading \& Kazwaini, 2014). The existence of plants around the waters will affect the presence of oxygen needed by aquatic biota. This condition allows aquatic animals to live and grow well and become predators (Ernamaiyanti, Kasry, \& Abidin, 2010).

According to Bustam \& Erniwati (2012), Anopheles larvae can tolerate the lowest pH of 4 and the highest $\mathrm{pH}$ of 11 and The environmental $\mathrm{pH}$ for the breeding of Anopheles larvae is 68 (WHO, 1975). In this study, the $\mathrm{pH}$ of water is 5-6. This finding is in accordance with the results obtained by Pandji, Endang, \& Firda (2012), who stated that water pH of 6.5-9 is conducive to the development of aquatic animals including Anopheles larvae. Habitat for breeding Anopheles spp. namely $\mathrm{pH} 7$ and is a suitable condition for larvae. Water $\mathrm{pH}$ affects the level of water fertility and microorganisms. At low $\mathrm{pH}$ (high acidity) the oxygen reserves will decrease and the rate of oxygen consumption decreases also (Rahman, Ihsak, \& Ibrahim, 2013). 
Based on the criteria for water temperature at the time of observation, no significant difference in water temperature was in water temperature was found among rice fields. water channel, and vehicle tread. The highest number of Anopheles larvae was ound in was found in water with temperature of $29^{\circ} \mathrm{C}-31^{\circ} \mathrm{C}$. The temperature at the sampling location was included in the good category for breeding mosquito larvae and providing good conditions for hatching mosquito eggs.

Purnawati (2016) stated that the water temperature of mosquito breeding habitats affects the hatchability of Anopheles eggs. The best hatchability occurs at high water temperatures.

Light intensity is a limiting factor for the presence of mosquito larvae. Species of mosquito larvae have different tolerance to light intensity. In this, the light intensity ranged from 756 $\mathrm{mmHg}$ to $761 \mathrm{mmHg}$. According to Hariyanto (2000), sunlight exerts different effects on the growth of Anopheles larvae. Some types of Anopheles prefer open spaces or shade. Anopheles punctulatus and Anopheles hyrcanus prefer open spaces, Anopheles sundaicus prefers shady places, and Anopheles barbirostis can live under open or shaded conditions.

In this study, An. vagus, An. kochi, and An. barbirostris preferred shade conditions with moderate sunlight intensity. According to Ibrahim, Ishak, \& Rahman (2013), turbid water can inhibit the penetration of light and result in disruption of photosynthesis. Photosynthesis in water affects the presence of dissolved oxygen, and consequently the density of mosquito larvae in breeding sites. About $80 \%$ of the habitats of Anopheles larvae have nonflowing water, and muddy substrates. Nurmaini (2003) reported that, habitats with calm or slightly flowing water such as rice fields are the favored breeding places of An. acunitus, An. vagus, An.barbirotus, and An. anullaris. Kazwaini and Martini (2006) also indicated that Anopheles mosquitoes prefer waterlogged or watery places with soil substrate, and clear, and flowing or inundated water.

\subsection{Diversity, Density, Dominance Index, and Pattern Distribution of Anopheles Larvae}

The species diversity index of Anopheles larvae was calculated and found to be within 0.040.36. The highest species diversity was found in paddy fields, and the lowest was detected in water channels. According to Magurran (1988), places with diversity value <1 are included in the low category by Shannon Winner index. Low diversity is thought to be due to high rainfall during observation. Tulak, Handoko, Hidayat, Hadi, \& Hakim (2018) explained that rainfall is one of the factors that influence the proliferation of Anopheles spp. The high intensity of rainfall can rinse Anopheles larvae thereby reducing their number and diversity.

The density ranged from 0.1 to 2.5 larvae/stab. The difference in the density of the same habitat type is thought to be influenced by physical conditions and water temperature. In additionthe existence of predators is believed to influence the number of larvae. Kazwaini and Martini (2006) reported that the density of Anopheles larvae is influenced by the presence of natural predators, such as tadpoles and tin head fish. The presence of predators also affects the breeding of larvae.

The predominance index of Anopheles larvae ranged from 0.01 to 1 . The dominance index was the highest in male Anopheles and the lowest in An. kochi and An. barbirostris. The dominance index describes index the condition of the actual population density in a place. According to Kazwari and Martini (2006), the high dominance of male Anopheles species is 
influenced by their better adaptation to breed in various habitat types than female than female Anopheles.

The distribution pattern of Anopheles spp was determined as uniform and group based on the Morishita index. The Morishita (Id) index value of $<1$ means that the distribution is uniform, and that of Id $>1$ shows that the distribution is grouped. The spread pattern tends to be uniform. According to Gama, Amin, \& Madaniatul (2013), mosquitoes have a uniform distribution because the environmental, physical, and chemical factors observed are relatively uniform and do not differ from one location to another. Based on these results, the abiotic and biotic environmental characteristics at the observation sites that tend to be uniform are thought to be opportunities for distribution of Anopheles spp in these areas.

Rain can cause the distribution of mosquitoes to be less or spread evenly. According to Mardiana \& Perwitasari (2010), the distribution of pre-adult Anopheles spp. in various habitats might occur due to changes in seasons. If the rainfall is high for a long time, then mosquito larvae can be carried by water flow, leading to a small number of larvae. By contrast, the dry season causes the breeding area to experience drought so mosquitoes will find a better breeding place.

The mapping results showed that most of the habitats of Anopheles spp. are located near residential areas. According to Widjaja (2012), breeding habitats that are close to residential areas are at risk of malaria. In addition, the risk of malaria transmission depends on Anopheles flight distance which is usually $2-3 \mathrm{~km}$ from the breeding habitat.

\section{Conclusion}

The following conclusions are established based on the results that the breeding habitats of Anopheles sp. in the Kelurahan Kemelak Bindung Langit in OKU Regency, South Sumatra are paddy fields, waterways, and vehicle wheels These habitats have water $\mathrm{pH}$ of 5-6, the water temperature of $28-32^{0} \mathrm{C}$, light intensity of $756-761 \mathrm{mmHg}$, visual clear water, muddy substrate, and distance of 10-60 m residential places. The species of Anopheles found are An. vagus, An. barbirostris, An, kochi, and male Anopheles. The dominant habitat is rice fields where the distribution of Anopheles larve os group and uniform.

\section{Acknowledgements}

The research was funded by the Competitive Research Fund of Sriwijaya University with contract number 0015/UN9/SK.LP2M.PT/2019 dated 21 June 2019. Also, thanks to Giri, Farah, and Winda, who are really helpful while conducting the research.

\section{Author Contributions}

Giri Maretasari contributed on sampling, sorting and identification of species. Yuanita Windusari carried out the data analysis and description of habitat characteristics. Laila Hanum developed data analysis of species diversity. Safrina Lamin conducted identification of species and habitat analysis. Dwi Septiawati carried out the habitat analysis.

\section{References}

Bustam, R., \& Erniwati. (2012). Karakteristik Tempat Perkembangbiakan Larva Anopheles Di Desa Bulubete Kecamatan Dolo Selatan Kabupaten Sigi Provinsisulawesi Tengah 
(Characteristics of Anopheles Larva Breeding Place in Bulubete Village, South Dolo District, Sigi Regency, Central Sulawesi Province). Makassar: Hasanuddin University. Retrieved from http://repository.unhas.ac.id/handle/123456789/3335

Ernamaiyanti, Kasry, A., \& Abidin, Z. (2010). Ecological Factors of Anopheles larvae habitat in Muara Kelantan Village, Mandau River District, Siak Regency, Riau Province in 2009 (Faktor-Faktor Ekologis Habitat Larva Nyamuk Anopheles di Desa Muara Kelantan Kecamatan Sungai Mandau Kabupaten Siak Provinsi Riau Tahun 2009). Journal of Environmental Science, 2(4), 92-102. Retrieved from https://docplayer.info/30000768Faktor-faktor-ekologis-habitat-larva-nyamuk-anopheles-di-desa-muara-kelantankecamatan-sungai-mandau-kabupaten-siak-provinsi-riau-tahun-2009.html

Gama, P. Z., Amin, S. L, \& Madaniatul, I. (2013). Distribusi dan Komposisi Nyamuk di Wilayah Mojokerto (Distribution and Composition of Mosquitoes in the Mojokerto Region). Journal of Biotropics, 1(2), 1-6. Retrieved from https://biotropika.ub.ac.id/index.php/biotropika/article/viewFile/143/119

Hariyanto, P. N. (2000). Malaria Epidemiology, Pathogenesis, Clinical Manifestations, and Treatment. Jakarta: EGC.

Ibrahim, E., Ishak, H., \& Rahman, R. R. (2013). Hubungan Karakteristik Lingkungan Breeding site dengan densitas larva Anopheles di Wilayah kerja Puskesmas Durikumba Kecamatan Karossa Kab. Mamuju Tengah (The Relationship Between Environmental Characteristics of Breeding Site and Density of Anopheles Larva in Work Area of Durikumba Health Center Karossa Subdistrict Central Mamuju Regency). Makassar: Universitas Hassanuddin. Retrieved from http://repository.unhas.ac.id/handle/123456789/5419

Imron, T. A., \& Munif, A. (2010). Malaria Vector Mosquito Observation Guide. Jakarta: Sagung Seto. Retrieved from https://www.semanticscholar.org/paper/PANDUANPENGAMATAN-NYAMUK-VEKTOR-MALARIA-Ta-

Munif/46651530fadd60ffb5fdb4c94842bfca7433b7dc

Kardinan, A., \& Dhalimi, A. (2010). Potential of Fennel (Foeniculum vulgare) as Active Ingredients for Anti Mosquito Dengue Lotion (Aedes aegypti). Buletin Penelitian Tanaman Rempah dan Obat, 21(1), 61-68. Retrieved from https://docplayer.info/40792853-Potensiadas-foeniculum-vulgare-sebagai-bahan-aktif-lotion-anti-nyamuk-demam-berdarahaedes-aegypti.html

Kazwaini, M., \& Martini, S. (2006). Tempat Perindukan Vektor, Spesies Nyamuk Anopheles, dan Pengaruh Jarak Tempat Perindukan Vektor Nyamuk Anopheles terhadap Kejadian Malaria pada Balita (Vector Breeding Places, Anopheles Mosquito Species, and Distance Effect of Anopheles Mosquito Vector Breeding Places on the Occurrence of Malaria in Toddlers). Jurnal Kesehatan Lingkungan Unair, 2(2), 173-182. Retrieved from https://www.neliti.com/id/publications/3960/tempat-perindukan-vektor-spesies-nyamukanopheles-dan-pengaruh-jarak-tempat-peri

Mading, M., \& Kazwaini, M. (2014). Ekologi Anopheles spp. di Kabupaten Lombok Tengah (Ecology of Anopheles spp. at Middle Lombok Tengah District). Aspirator, 6(1), 13-20. Retrieved from http://ejournal.litbang.depkes.go.id/index.php/aspirator/article/view/3518 Mahdalena, V., \& Tanwirotun, N. (2016). Ekologi Nyamuk Anopheles spp. Di Kecamatan Lengkiti, Ogan Komering Ulu, Sumatera Selatan Tahun 2004-2015 (Anopheles Spp. in Lengkiti District, Ogan Komering Ulu, South Sumatra in 2004-2015). Sprirakel, 8(2), 27 - 
36.

http://ejournal.litbang.depkes.go.id/index.php/spirakel/article/view/6167

Magurran, A. E. (1988). Ecological Diversity and Its Measurement. New Jersey: Princeton University Press. https://doi.org/10.1007/978-94-015-7358-0

Mandasari, V. (2012). Karakteristik Habitat Potensial Larva Nyamuk Anopheles dan Hubungannya dengan Kejadian Malaria di Kota Pangkalpinang, Bangka Belitung (Characteristics of Potential Habitat of Anopheles Mosquito Larvae and Its Relationship with the Occurrence of Malaria in the City of Pangkalpinang, Bangka Belitung). Bogor: Bogor Agricultural University. Retrieved from https://repository.ipb.ac.id/handle/123456789/58934

Mardiana, \& Perwitasari, D. (2010). Habitat yang Potensial untuk Anopheles Vagus di Kecamatan Labuan dan Kecamatan Sumur Kabupaten Pandeglang, Provinsi Banten (Potential Anopheles Vagus Habitat in Labuan District and Sumur District Pandeglang Regency, Banten Province). Jurnal Ekologi Kesehatan, 9(1), 1139-1143. Retrieved from http://ejournal.litbang.depkes.go.id/index.php/jek/article/view/5404

Mardiana, Shinta, Wigati, Enny, W.L., \& Sukijo. (2002). Berbagai Jenis Nyamuk Anopheles dan Tempat Perindukannya yang Ditemukan di Kabupaten Trenggalek, Jawa Timur (Various Types of Anopheles Mosquitoes and Breeding Places Found in Trenggalek Regency, East Java). Media Litbang Kesehatan, 12(4), 30-36. Retrieved from http://ejournal.litbang.depkes.go.id/index.php/MPK/article/view/1060

Maretasari. (2019). Karakteristik habitat dan sebaran larvaw Anopheles spp berdasarkan faktor lingkungan di kelurahan kemelak bindung langit kabupaten Ogan Komering Ulu (OKU) Sumatera Selatan (Habitat characteristics and the distribution of Anopheles spp larvae based on environmental factors in the kelelak protected sky village of Ogan Komering Ulu (OKU), South Sumatra). Universitas Sriwijaya.

Ministry of Health of the Republic of Indonesia. (2003). Modul Entomologi Malaria 3 (Malaria Entomology Module 3). Jakarta: Direktorat Jenderal PPM \& PLP. Direktorat Pemberantasan Penyakit Bersumber Binatang.

Ministry of Health of the Republic of Indonesia. (2017). Profil kesehatan OKU Timur Sumatera Selatan tahun 2016 (Health Profile of OKU Timur, South Sumatra in 2016).

Munif, A. (2005). Bionomi as the Basis of Malaria Vector Control in Lengkong District, Sukabumi Regency. Center for Health Ecology Research and Development, Health Research and Development Agency, Ministry of Health, Republic of Indonesia.

Nurhayati, H. L., Hasanudin, I., \& Anwar. (2015). Karakteristik tempat perkembangbiakan Anopheles sp. di wilayah kerja Puskesmas Bonto Bahari Kabupaten Bulukumba (Characteristic of Anopheles sp. Breeding Site in Area Puskesmas Bonto Bahari Bulukumba District). Jurnal Kesehatan, 1(1), 1-15. Retrieved from http://repository.unhas.ac.id/handle/123456789/10792

Nurmaini. (2003). Mengidentifikasi Vektor dan Pengendalian Nyamuk Anopheles aconitus secara sederhana (Simple vector identification and control of Anopheles aconitus). Medan: USU digital library.

O’Connor, C.T., \& Soepanto, A. (1999). Kunci bergambar untuk Anopheles spp betina di Indonesia (The pictorial key for Anopheles spp females in Indonesia). Jakarta: Depkes RI. 
Odum, E.P. (1993). Dasar-dasar Ekologi (Fundamentals of Ecology), translated by Tjahjono Samingan. Jogjakarta: Gadjah Mada University Press.

Pandji, W. D., Endang, P. A., \& Firda, Y. P. (2012). Studi Bioekologi Nyamuk Anopheles Sundaicus di Desa Sukaresik Kecamatan Sidamulih Kabupaten Ciamis (Bioecological Study of Anopheles sundaicus Mosquito in Sukaresik Village, Sidamulih District, Ciamis Regency). Bulletin of Health Research, 41(1), 26-36. Retrieved from http://ejournal.litbang.depkes.go.id/index.php/BPK/article/view/3056

Permadi, W. D. S., Lasbudi, P. A., \& Yahya. (2018). Identifikasi Nyamuk Dewasa pada Buah Kelapa di Kelurahan Kemelak Kabupaten Ogan Komering Ulu (Identification of Adult Mosquitoes in Coconut Fruit in Kemelak Village, Ogan Komering Ulu Regency). Bioma 7(2), 154-160. Retrieved from http://journal.upgris.ac.id/index.php/bioma/article/view/2797

Purnawati, N. (2016). Analisis Spasial Keberadaan Breeding Place Vektor Dengan Kejadian Malaria di Desa Lebakwangi Kecamatan Pagedongan Kabupaten Banjarnegara (Spatial Analysis of the Existence of Vector Breeding Place with the Occurrence of Malaria in Lebakwangi Village, Pagedongan District, Banjarnegara Regency). Semarang: Universitas Negeri Semarang. Retrieved from https://lib.unnes.ac.id/26235/

Putra, T. R. I. (2011). Malaria dan permasalahannya (Malaria and its problems). Medical Journal, 11(2), 103-114. Retrieved from http://jurnal.unsyiah.ac.id/JKS/article/view/3469

Rahman, R. R., Ishak, H., \& Ibrahim, E. (2013). Relationship between Environmental Characteristics of Breeding Site with Anopheles Larva Density in the Work Area of Durikumba Health Center, Karossa Koh District, Midle Mamuju.

Santoso, B. (2002). Studi Karakteristik habitat larva Nyamuk Anopheles maculates Theobold dan Anopheles balabacensis Baisas Serta beberapa faktor yang mempengaruhi populasi larva di desa Hargotirto, Kecamatan kokap, Kabupaten Kulonprogo, DIY (Study on the characteristics of larvae habitat of Anopheles maculates Theobold and Anopheles balabacensis Baisas As well as several factors that affect larval populations in the village of Hargotirto, Kokap District, Kulonprogo Regency, DIY). Bogor: Institut Pertanian Bogor. Retrieved from https://repository.ipb.ac.id/handle/123456789/7522

Soekirno, M., Ariati, Y., \& Mardiana, M. (2002). Jenis-jenis Nyamuk yang Ditemukan di Kabupaten Sumbawa, Provinsi Nusa Tenggara Barat (Types of Mosquitoes Found in Sumbawa Regency, West Nusa Tenggara Province). Jurnal Ekologi Kesehatan, 5(1), 356360. Retrieved from http://ejournal.litbang.depkes.go.id/index.php/jek/article/view/1613 Susanna, D. (2010). The Dynamics of Malaria Transmission. Jakarta: Universitas Indonesia. Susanto, A. (2013). Pengaruh Modifikasi Iklim Mikro dengan Vegetasi Ruang Terbuka Hijau (RTH) dalam Pengendalian Penyakit Malaria (The effect of Micro Climate Modification with Green Open Space Vegetation to Control of Malaria Disease). Spirakel, 5(1), 1-11. Retrieved from http://ejournal.litbang.depkes.go.id/index.php/spirakel/article/view/6148

Tulak, N., Handoko, Hidayat, R., Hadi, U. K., \& Hakim, L. (2018). Karakteristik dan Distribusi Spasial Habitat Positif Larva Nyamuk Anopheles spp. berdasarkan Curah Hujan (Characteristics and Distribution of Positive Habitats Anopheles spp. based on Rainfall). Jurnal MKMI, 14(3), 1-12. $\quad$ Retrieved from https://media.neliti.com/media/publications/267625-none-d5e1e9b9.pdf 
Widjaja, J. (2012). Pola Spasial Kasus Malaria Di Desa Santu'un Kecamatan Muara Uya Kabuaten Tabalong Provinsi Kalimantan Selatan (Spatial Pattern of Malaria Cases in Santu'un Village, Muara Uya District, Tabalong Regency, South Kalimantan Province). Journal of Disease Vectors, 6(1), http://ejournal.litbang.depkes.go.id/index.php/vektorp/article/view/7479 WHO. (1975). Manual on Practical Entomology in Malaria Part I dan II. Geneva: WHO. 